\title{
RURAL LAND REFORM IN SOCIALIST ETHIOPIA: THE FIRST YEAR
}

\author{
Harrison C. DunNing
}

On March 4, 1975, Ethiopia's Provisional Military Administration Council proclaimed a sweeping reform of rural land-holding. In a dramatic break with an historic tangle of land tenure conditions, the military government declared all rural lands to be "the collective property of the Ethiopian people"1; hired labor to cultivate holdings to be prohibited ${ }^{2}$; and local peasant associations to be the chosen means for building a new agrarian structure. This proclamation was but one in a series of measures designed to implement the decision taken on December 13, 1974, to establish Ethiopia as a socialist state ${ }^{3}$. Related proclamations provide for the nationalization of many business activities ${ }^{4}$ and of urban lands and "extra" houses".

These measures represent a revolutionary departure from the constant support for politically powerful land-based provincial and national elites provided by the late Haile Sellassie's government. They rest on the political philosophy, expressed in the Rural Lands Proclamation, that "it is essential to fundamentally alter the existing agrarian relations so that the Ethiopian peasant masses which have paid so much in sweat as in blood to maintain an extravagant feudal class may be liberated from age-old feudal oppression, injustice, poverty, and disease ..." They aim to lay the basis for a new socio-economic-political order in Ethiopia, although at present the nature of the new order is far from clear. This article will review the major provisions of the Rural Lands Proclamation itself; provide some impressions of the implementation experience with that proclamation during its first year; and review a more recent proclamation which represents a pronounced change from the "land to the tiller" concept of the Rural Lands Proclamation.

\section{Phase One Theory: Land to the Tiller}

Prior to the Revolution, two principal views on land reform existed among those who purported to favor a change in traditional systems: an "official" line and a "student" line. The official line was developed following the abortive coup d'état of 1960. It emphasized the development of a series of modest legislative proposals, which dealt with tenure reform in the northern highlands, the so-called "com-

\footnotetext{
1 A Proclamation to Provide for the Public Ownership of Rural Lands, Proclamation No. 31 of 1975 , Art. 3 (1), Negarit Gazeta 34th Year No. 26 (April 29, 1975), hereinafter "Rural Lands Proclamation".

2 Rural Lands Proclamation, Art. 4 (5). Limited exceptions are made, e.g. for a woman with no other adequate means of livelihood. Although the prohibition appears in an article whose heading refers to land redistribution, which is authorized only for the southern provinces, it was apparently intended to apply to all rural lands except state farms. In any event it has not been the practice of the government to enforce this prohibition, for example in the coffee-growing areas of the southwest where seasonal hired labor is vital to the agricultural economy.

3 B. Thomson, Ethiopia: The Country That Cut Off Its Head (London, 1975), p. 131.

4 A Proclamation to Provide for the Ownership and Control by the Government of the Means of Production, Proclamation No. 26 of 1975, Negarit Gazeta 34th Year No. 22 (March 11, 1975).

5 A Proclamation to Provide for Government Ownership of Urban Lands and Extra Urban Houses, Proclamation No. 47 of 1975, Negarit Gazeta 34th Year No. 41 (July 26, 1975).

6 Rural Lands Proclamation, preamble.
} 
munal" tenure region; agricultural tenancy reform; cadastral survey and title registration; land tax reform, including progressive taxation of unutilized lands; and abolition of the practice of granting government land in individual ownership to politically loyal persons ${ }^{7}$. The most radical official proposal came in 1973, when the Ministry of Land Reform and Administration urged consideration of expropriation and redistribution of holdings in excess of a ceiling ${ }^{8}$. In fact, however, a combination of Parliamentary opposition and lack of political will on the part of the executive meant that very little of what was proposed was ever enacted into $\mathrm{law}^{9}$. In the political circumstances of the monarchy, significant land reform seemed to be an impossibility.

In contrast to the official line, the student line during the last few years of the monarchy was direct and radical. Students vigorously supported the first agricultural tenancy reform bill when it came before Parliament in 1965, and particularly with the formation of the University Students Union of Addis Ababa in 1967 "land to the tiller" became the slogan of the student movement. The necessary corollary was that absentee owners should be deprived of their rights to land or to its fruits.

In 1974, as the power of Haile Sellassie's regime waned and military groups moved to fill the vacuum ${ }^{10}$, significant rural land reform became politically realistic for the first time. A civilian cabinet formed on the advice of the military took up the most radical of those proposals earlier developed by the Ministry of Land Reform and Administration. In April 1974 the land reform policy was stated to be as follows: "Holdings in excess of what is considered a reasonable limit of the owner's capacity to develop will be taken over by the Government and will be distributed to those who will make their living by working on the land ${ }^{11}$." Compensation was to be paid for expropriated land.

Nearly a year was to pass, however, before promulgation of the Rural Lands Proclamation. Meanwhile the controlling military group became increasingly socialist in its orientation, the leadership changed in the Ministry of Land Reform and Administration ${ }^{12}$, and successive drafts of the legislation became more and more restrictive of private land ownership. Finally the notions both of continued private ownership of rural land, with a ceiling, and of compensation for expropriated land were abandoned in favor of immediate, uncompensated public ownership of all rural land. Under this new scheme, three matters are of particular interest: the tenure system built upon the base of public ownership, the provisions made for compensation for expropriated assets other than the land itself, and use of "peasant associations" as the means for constructing new agrarian patterns.

\footnotetext{
7 See H. Dunning, "Land Reform in Ethiopia: A Case Study in Non-Development", 18 UCLA Law Review 271-307'(1970); J. Cohen \& D. Weintraub, Land and Peasants in Imperial Ethiopia (Assen, The Netherlands, 1975); and J. Bruce, "Ethiopia: Nationalization of Rural Lands Proclamation, 1975", University of Wisconsin Land Tenure Center Newsletter, No. 47 (January-March 1975).

8 Bruce, op. cit. note 7.

9 Cohen \& Weintraub, op. cit. note 7, p. 93.

10 See generally Thomson, op. cit. note 3

11 “New Cabinet Issues Policy Declaration", Ethiopian Herald, April 9, 1974.

12 Bruce, op. cit. note 7.
} 


\section{A. Tenure}

The tenure system of the Rural Lands Proclamation is not without complication. Although all rural land is collectively owned by the Ethiopian people, title does not seem to be vested in the state, for the national government is given the power to expropriate "land belonging to peasant associations" ${ }^{13}$ ". Nor is there in the legislation any explicit statement that title to land is vested in the peasant associations, although the associations' functions with regard to land distribution suggest as much ${ }^{14}$. While such questions as to the nature of the ultimate title may be rather theoretical, there are also uncertainties regarding the more practical question of the legal position of cultivators. With limited exceptions ${ }^{15}$, the cultivator, if formerly a tenant or a hired laborer, is confirmed in a non-transferable "possessory right" over the land he tills (or, presumably, uses for grazing ${ }^{16}$ ). This possessory right continues only so long as the cultivator or certain successors work the particular holding ${ }^{17}$, and in any event in the southern provinces the Rural Lands Proclamation states that the possessory right exists only until peasant associations allot their lands to cultivators in roughly equal parcels ${ }^{18}$. No such allotment is to exceed ten hectares ${ }^{19}$. Once such redistribution occurs, the allottees apparently are to have the same sort of possessory right as is specified for the pre-redistribution phase ${ }^{20}$.

Tenants and hired laborers are not, however, the only ones confirmed in possessory rights. "Resident" landowners who have leased all their land have the right to take possession of a share equal to that of the tenants ${ }^{21}$. Presumably landowners who were cultivating their own parcels are also confirmed in possessory rights, although for the southern provinces this is not made explicit in the legislation. And for "communal" and nomadic lands possessory rights are confirmed respectively for lands the cultivators presently till and for those the nomads presently use for grazing ${ }^{22}$, except that cultivators in communal tenure areas who have been tenants of some land and owners of other land - a very common situation in these areas - are not confirmed in possessory rights over land they have cultivated as tenants ${ }^{23}$.

By the establishment of this new land tenure system based upon public ownership and private cultivation rights, the Ethiopian government has in theory swept away both the oppressive tenancy system which prevailed in the southern freehold regions and the descent or village-based tenures of the northern highlands. The southern lands were largely "conquest" lands, which fell under northern, mostly Shoan, control after the victories of the armies of Menilek II in the latter

13 Rural Lands Proclamation, Art. 17 (1).

14 Rural Lands Proclamation, Art. 10 (1) (2). For example, an exception is made with regard to one who rented land from a woman with no other adequate means of livelihood.

16 Rural Lands Proclamation, Art. 6 (1), Art. 19. This does not appear to apply to "large-scale" farms. Id. at Art. 7.

17 The successors are a surviving spouse or children. Rural Lands Proclamation, Art. 5. If there are no such survivors, the holding is apparently to be reallocated by the peasant associations.

18 Rural Lands Proclamation, Art. 4 (4).

19 Rural Lands Proclamation, Art. 4 (3).

20 Unfortunately this right has been widely described as a "usufruct". Bruce, op. cit. note 7; Addis Hiwet, Ethiopia: From Autocracy to Revolution (London, 1975), pp. 112-113. This invites confusion with the civil law usufruct, which does not require the holder to be in possession or cultivation of the land. See Civil Code of Ethiopia, Art. 1309.

21 Rural Lands Proclamation, Art. 6 (1). How this is to be done where the tenants have unequal holdings is unclear, as is the nature of "residence" of one who has leased all of his land.

22 Rural Lands Proclamation, Art. 19 and Art. 24.

23 Rural Lands Proclamation, Art. 22 (2). 
part of the nineteenth century ${ }^{24}$. In many of these southern areas, it appears effective control of land and land revenues was established only as recently as the $1930 \mathrm{~s}^{25}$. Given the origin of the system, the ethnic and cultural differences between the tenants and the landlords, and the high rents demanded in most of the share-cropping arrangements, widespread acceptance of the reforms by cultivators was to be expected.

The situation is entirely different in the northern highlands, where most cultivators had land held individually, but subject to certain group controls ${ }^{26}$; where the land tenure systems were dynamic ones interwoven in the basic fabric of local social and political organization ${ }^{27}$; where historically there has been enormous suspicion of the motives of central government tampering with land tenure ${ }^{28}$; and where fragmentation of holdings, rather than oppressive tenancy conditions, has appeared to many to be the major land tenure constraint upon increased agricultural productivity. Here widespread acceptance by peasants, much less by the local gentry, could not be expected. By tying private cultivation rights to existing allocations, the Rural Lands Proclamation freezes what had been a dynamic system. Further it prohibits all peasant obligations to pay dues to local officials or representatives of the landed gentry ${ }^{29}$. Such dues, for example gult which represented tribute paid by a taxpayer to a private individual as assignee of the state, are a remnant of the feudal land tenure system which historically prevailed in these northern areas ${ }^{30}$. Such payments were in principle abolished ten years $\mathrm{ago}^{31}$, but they seem in fact to have been continued in practice in some $\operatorname{areas}^{32}$. By once again abolishing such payments, the Rural Lands Proclamation attempts to eliminate part of the economic base of the rural elites in northern areas. Similarly, by failing to include any saving provision for church lands, the legislation attempts to eliminate much of the land-related economic base of the Ethiopian Orthodox Church ${ }^{33}$.

\section{B. Compensation}

Although under the Rural Lands Proclamation no compensation is to be paid for expropriated land ${ }^{34}$, provision is made for "fair compensation" for movable properties and permanent works on the land ${ }^{35}$. Tree crops, including coffee, are

24 For the view that this imperial expansion was "an ingathering of peoples with deep historical affinities" rather than "a subjugation of alien peoples", see D. Levine, Greater Ethiopia: The Evolution of a Multiethnic Society (Chicago, 1974), p. 26, passim.

25 See A. Lexander, Land Ownership, Tenancy and Social Organization in the Waiji Area (CADU publication no. 50, 1970), p. 74.

26 Ordinarily this was the descent-based rist or the village-based deissa. In the north landless persons have usually been either members of artisan castes or, in some regions, Muslims.

27 See A. Hoben, Land Tenure amoung the Amhara of Ethiopia: The Dynamics of Cognatic Descent (Chicago, 1973).

28 See Hoben, id. at pp. 217-226.

29 Rural Lands Proclamation, Art. 21.

30 For extensive references to the existence of "feudalism" in Ethiopia, see J. Cohen, "Ethiopia: a Survey on the Existence of a Feudal Peasantry", The Journal of Modern African Studies pp. 665-672 (1974).

31 A Proclamation to Amend the Land Tax Proclamation of 1944, Proclamation No. 230 of 1966, Art. 2 (b), Negarit Gazeta 25th Year No. 9 (A) (March 7, 1966).

32 Cohen \& Weintraub, op. cit. note 7, p. 82.

33 In the frequent cases where clergy receive their material sustenance by the cultivation of church land, Cohen \& Weintraub, id. at p. 41, the clergy-cultivator is confirmed in his possessory right like any other cultivator.

34 Rural Lands Proclamation, Art. 3 (3)

35 Rural Lands Proclamation, Art. 3 (3), Art. 7 (2) and see Art. 6 (4). The legislation contains no provision explicitly expropriating "movable properties" and "permanent works on the land", although the latter should perhaps be viewed as part of "all rural lands" nationalized by Article 3 (1), at least to 
explicitly excluded from compensation ${ }^{36}$. The Rural Lands Proclamation provides that the Minister of Land Reform and Administration (now the Minister of Lands and Settlement) shall determine the compensation to be paid in respect of movable properties and permanent works on "large-scale" farms $s^{37}$, but subsequent legislation establishes a Compensation Commission with general powers to fix the compensation provided for in legislation expropriating businesses, rural and urban lands, and private schools ${ }^{38}$. This legislation contains no further standards for fixing compensation; instead, the commission is instructed to "negotiate and reach agreements with compensation claimants ... as to the amount of compensation payable and the manner of payment thereof ${ }^{39}$." Given the comprehensive character of the nationalizations, Ethiopia's socialist philosophy, and the country's very limited financial resources, the "fair compensation" provision of the Rural Lands Proclamation is unlikely to mean claimants will receive immediate payment of the market value of their expropriated movable properties and permanent works on the land.

\section{Peasant Associations}

Peasant associations are fundamental to the Ethiopian rural land reforms, for they are the means to mobilize the peasantry and ensure implementation of the new land tenure system. Indeed, some have viewed them as the basic elements in a new local government structure, or a new popular political party, or both. Their development certainly will be a crucial aspect of rural social change in the new Ethiopian order.

According to the Rural Lands Proclamation, membership in the peasant association is voluntary and is open to former tenants, landless persons, and hired agricultural workers of landowners who had less than ten hectares of land ${ }^{40}$. Each association takes as a geographic base the area formerly under a chika shum ${ }^{41}$, who was the lowest official in the former local government hierarchy. In addition to these associations of the mass of peasants themselves, provision is made for peasant associations at the sub-district (woreda) and district (awraja) levels, in each case composed of delegates from the associations below ${ }^{42}$.

\footnotetext{
the extent they meet the definition of permanent works as “irrigation works, water wells, buildings and other works made of stone, concrete, bricks, metal or any combinations thereof". Id. at Art. 2 (7). Apparently one basis for the expropriation of movables is the provision regarding large-scale farms that they "shall be organized as a State or a co-operative farm or shall be allotted to tillers." Id. at Art. 7 (1). they "shall be organized as a State or a co-operative farm or shall be allotted to tillers. Id. at Art. 7 (1). Art. 2 (2). Another basis for the expropriation of movables is the provision that a tenant "shall have the right to retain agricultural implements and a pair of farm oxen belonging to the landowner within a period not exceeding three years..." Id. at Art. 6 (4).

38 A Proclamation to Provide for the Establishment of a Compensation Commission, Proclamation No. 70 of 1975, Negarit Gazeta 35th Year No. 14 (December 13, 1975). Members of the commission were appointed in February 1976.

39 Id. at Art. 7 (4). For the time being those who were deprived of extra houses in urban areas and have no other adequate source of income receive half of their previous rental revenue, up to a maximum of Eth. \$250 per month (US \$1.00 = Eth. \$2.07).

40 Rural Lands Proclamation, Art. 9. Former owners of larger quantities of land may join once redistribution is completed. Ibid. The associations themselves were not given legal personality by the Rural Lands Proclamation, but this was provided by subsequent legislation. A Proclamation to Provide for the Organization and Consolidation of Peasant Associations, Proclamation No. 71 of 1975, Negarit Gazeta 35th Year No. 15 (December 14, 1975) Art. 4.

41 Rural Lands Proclamation, Art. 8. The minimum area for an association is eight hundred hectares. Ibid. Some field reports indicate chika shum boundaries of ten have not been followed. Hunting Technical Services Limited, “Tigrai Rural Development Study", Annex 8, "Social Organization" (draft, December 1975), p. 28.

42 Rural Lands Proclamation, Art. 11.
} 
Numerous important functions are assigned by the Rural Lands Proclamation to the peasant associations. These include the administration of public property within the association's area; the establishment of co-operatives; the construction of schools, clinics and similar institutions; and the undertaking of villagization programs ${ }^{43}$. Of particular importance, the legislation anticipates that once peasants in the southern freehold areas have been confirmed in their possessory rights, land will be redistributed to farming families in parcels "as far as possible ... equal44." Such redistribution is to be carried out on the initiative of the peasant association itself, with assistance provided by the government only where solicited ${ }^{45}$. Furthermore, in order to prevent the courts from blocking implementation of the reforms, the Rural Lands Proclamation provides for tribunals for peasant associations and gives these tribunals exclusive jurisdiction over land disputes ${ }^{46}$.

\section{Phase One Practice: Some Impressions}

No research group in Ethiopia has to date been able and willing to prepare a comprehensive analysis of the field experience during the first year of the Rural Lands Proclamation. Such a task is made particularly difficult because, as local officials are quick to comment, even within a single district the implementation experience has greatly differed from place to place. The Ministry of Lands and Settlement, which has reports from the field officers assigned, in principle, to each district in the country ${ }^{47}$, has much of the raw material necessary for such a comprehensive analysis. Local organizations in some cases possess the resources to prepare thorough analyses for their regions. CADU, a competent and well developed organization engaged in comprehensive rural development in a district in Arussi province ${ }^{48}$, has a planning and evaluation unit which has begun to gather necessary field data. The Institute of Development Research at Addis Ababa University is sponsoring similar research. The problems one encounters in such research in Ethiopia are formidable ${ }^{49}$, and the sort of detailed and well-supported comprehensive analysis dear to the heart of the academic (and perhaps even useful for the serious land reformer) may never appear. Despite the nearly total lack of field data and the confusing existence in Addis Ababa and in the countryside of many conflicting rumors as to the effects of the rural land reforms, an attempt will be made here to summarize the major features of phase one practice.

First, the production disasters freely foreseen by some observers as an immediate consequence of the reforms seem unlikely to have taken place ${ }^{50}$. The Rural Lands Proclamation was issued in early March, in the season of the "small rains" when sowing takes place in Ethiopia. The first concern was to get sowing accomplished on schedule, particularly on the large-scale mechanized farms being taken over

\footnotetext{
43 Rural Lands Proclamation, Art. 10. priority system for redistributions.

45 Rural Lands Proclamation, Art. 10 (1)

46 Rural Lands Proclamation, Art. 10 (4) and Art. 28.

47 Rural Lands Proclamation, Art. 12 (2).

48 See B. Nekby, CADU: An Ethiopian Experiment in Developing Peasant Farming (Stockholm, 1971).

49 See Cohen \& Weintraub, op. cit. note 7, at p. X.

50 Cohen \& Weintraub, op. cit. note 7 , at p. 108 , state that resulting production short falls will "undoubtedly" follow land reforms.
} 
from private entrepreneurs. This was done successfully for most of the large farms. No problems were experienced in peasant farming areas, where the legislation did not interfere with previous patterns of occupancy. The de facto ten hectare limit had little meaning for most cultivators, since the average holding is well below that limit ${ }^{51}$. Disruption, where it took place, seems to have centered upon inputs sometimes supplied by landlords, such as oxen and seed ${ }^{52}$. Fortuitously the weather was better than average through much of the country, and the government put special emphasis on the production of food crops on those large-scale mechanized ex-commercial farms which for the time being are being run as state farms. As a result, it appears there has not been any serious drop in production ${ }^{53}$, although of course a good harvest does not necessarily mean that adequate food supplies at acceptalbe prices will reach the cities when needed ${ }^{54}$.

Second, predictably the reforms have initially been far more successful in the south than in the north. "Land to the tiller" as a philosophy obviously fits much better in an area which has had a high rate of tenancy with heavy economic burdens placed upon the tenants than in one which has not had such a pattern. In some areas of the south tenants had previously been politicized by tenant evictions which followed the introduction by private entrepreneurs of mechanized farming ${ }^{55}$. Furthermore, the promise of redistribution may have been more welcome in the social context of the southern, largely Oromo, areas than in that of the northern, largely Amhara and Tigrean areas. One student of social organization in Ethiopia characterizes Oromo society as the antithesis of Amhara society as follows: "Where the Amhara system is hierarchical, the Oromo is egalitarian. Where the Amhara is individualistic, the Oromo is solidaristic ${ }^{56}$."

Government statistics on peasant association formation show that initially the rate of formation was more rapid in the southern highlands ${ }^{57}$, but that toward the end of the first year of the Rural Lands Proclamation the pace was picking up in the north ${ }^{58}$. Civil disturbances in some parts of the north have obviously had an inhibiting impact. In a few areas in "Amhara heartland" provinces such as Gojjam and Begemdir, it has been necessary to withdraw local land reform advisers. But elsewhere in the north peasant associations have been formed in sizable numbers ${ }^{59}$, and they appear to be giving rise to a new group of community leaders. According to a recent field study of social organization in Tigrai province, most members of the traditional elites have been explicitly excluded from membership in peasant association committees: previous local administrators (chika shum), previous local judges (atbia danya), rural nobles, rich people (ill-defined) and

51 Cohen \& Weintraub, op. cit. note 7, at p. 3, estimate that most Ethiopian peasants cultivate two hectares and use three hectares for pasture. Although the ten hectare maximum in the legislation applies only to allotments made pursuant to land redistribution, Rural Lands Proclamation, Art. 4 (3), many treat it as in effect even where such redistribution has not taken blace.

$52 \mathrm{M}$. Ottaway, "Land Reform and Peasant Associations in Ethiopia: A Preliminary Analysis" (paper for the annual meeting of the African Studies Associations, San Francisco, September 1975), p. 7.

53 In fact a study prepared at the United Nations Economic Commission for Africa estimates the most recent harvest to be approximately ten percent greater than the harvest for 1974/75. J. Dalton,

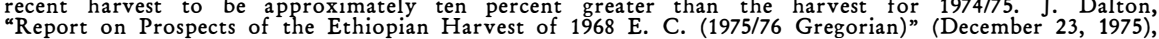
p. 4. There is dispute as to whether the $1974 / 75$ harvest was "average" or slightly below average.

$54 \mathrm{At}$ the end of the first year of the Rural Lands Proclamation, the Addis Ababa market was experiencing severe shortages of teff, a favored Ethiopian grain, but other grains were in good supply.

55 See Henock Kifle, "Investigations On Mechanized Farming \& Its Effects On Peasant Agriculture" (CADU publication No. 74, 1972)

56 Levine, op. cit. note 24 , at p. 128.

57 Statistics for September 1975 are provided at Ottaway, op. cit. note 52, at note 9.

58 Ministry of Lands and Settlement statistics for November 1975 (in Amharic).

59 Within Tigrai province associations are said to have been formed at "a remarkable pace". Hunting Technical Services Limited, op. cit. note 41, at p. 28. 
village elders ${ }^{60}$. Interestingly, however, in Tigrai province priests have not been excluded from leadership positions. In regard to the two most important positions, chairman and secretary of the peasant association, approximately twenty percent of incumbents in the associations studied were priests ${ }^{61}$.

In the north, the major function of peasant associations according to the Rural Lands Proclamation is "to induce and organize peasants into co-operative farms ${ }^{62}$." Land redistribution is clearly not among the functions given to northern peasant associations $s^{63}$, yet where such associations want to carry out redistribution it is the government's view that this is permitted. Indeed the Ministry of Lands and Settlement's first major involvement in local land redistribution is planned for Tigrai province.

Although peasant co-operatives have apparently not yet been organized in the northern provinces, some field reports indicate that in the initial stages some northern associations have required farmers to limit their claims to cultivation rights to land within the boundaries of a single association. Such action, which is not authorized by the legislation ${ }^{64}$, has the effect of limiting fragmentation and whatever adverse economic effects such fragmentation may have upon production $^{65}$. Where fragmentation had been dealt with by leasing arrangements farmers renting to others their distant parcels and renting from others parcels closer to their home base - some northern peasant associations reportedly have simply confirmed all cultivators in their existing occupancy. This is essentially what the Rural Lands Proclamation provides for the south ${ }^{66}$, but not the north ${ }^{67}$.

Third, the Ministry of Lands and Settlement has had insufficient resources to serve as the primary agent of change as anticipated by the Rural Lands Proclamation. Instead the major thrust initially came from the zemecha, a "Development Through Co-operation, Enlightenment, and Work Campaign" in which some sixty thousand secondary school students, recent secondary school graduates, and university students have been sent to the countryside to engage in a crash program of education, development and politicization of the peasantry ${ }^{68}$. No role for these students was anticipated in the Rural Lands Proclamation itself, but land reform work is one point in their eight point program ${ }^{69}$. Of these various tasks, land reform work has been paramount for many zemecha participants. Indeed many seem to have gone beyond explanation of the Rural Lands Proclamation and assistance in formation of peasant associations to unauthorized activities such as the disarming and occasionally arrest or killing of former landlords. Considerable antagonism between zemecha participants and local police forces has resulted, and it has been the pattern in most instances for the military government to support the police and restrain the students ${ }^{70}$. This pattern has contributed to the open hostility with which most students today regard the military regime.

60 Id. at p. 39. Illiterates are also exluded from the committees.

61 Id. at p. 40.

62 Rural Lands Proclamation, Art. 23.

63 Rural Lands Proclamation, Art. 10 (1) and Art. 23.

64 Rural Lands Proclamation, Art. 23

65 Although the undesirable economic effects of fragmentation are often noted, fragmentation may also serve to minimize the risk of total crop failure. Hoben, op. cit. note 27 , at p. 106, note 4.

66 Rural Lands Proclamation, Art. 6 (1).

67 Rural Lands Proclamation, Art. 22.

68 Initially, "concern with getting the students out of Addis was clearly much greater than concern with rural development and political education of the peasant masses..." Ottaway, op, cit. note 52, at p. 4.

69 The other points are as follows: the philosophy of Ethiopian socialism, health, basic education, infrastructure, agricultural improvement, cultural appreciation and the collection of demographic data.

70 See Ottaway, op. cit. note 52 , at pp. $7-8$. 


\section{Phase Two Theory: Toward a Socialist Agriculture}

On December 14, 1975, the Provisional Military Administration Council issued a second proclamation on rural land reform ${ }^{71}$. This legislation, the Peasant Associations Proclamation, suggests a decidedly different attitude toward land tenure than did the Rural Lands Proclamation. Gone is the emphasis on "land to the tiller", redistribution of lands to be cultivated by farming families in approximately equal parcels, and the peasant association as a means to accomplish this individualistic end. In the Peasant Associations Proclamation the word "distribution" is never used, although peasant associations are to continue to exercise the functions given them by the Rural Lands Proclamation ${ }^{72}$. One of these functions, for southern formerly freehold areas, is land distribution ${ }^{73}$.

In the Rural Lands Proclamation the peasant association was to serve the individual. In the Peasant Associations Proclamation the individual is to serve the association, as well as the service and producer co-operatives to be established by peasant associations: “. . . it is necessary to organize and develop co-operatives in all places and at all levels in order to lay down the foundation of socialist agriculture so that the peasantry may benefit from joint labour ${ }^{74}$." This new emphasis is particularly evident with regard to producers co-operatives. One of their objectives, for example, is "to put the main instruments of production under the control of, and when necessary to gradually transfer their ownership to, the society ${ }^{75}$." Another is "to divide members into working groups to enable them to work collectively for the society ... ${ }^{76}$ "

The Peasant Associations Proclamation thus anticipates that egalitarian values will be reflected in collective agricultural activity, rather than in individual holdings of equal size, although in collective production rewards will vary as members will be paid "according to the quality and quantity of their work 77 " Furthermore, the new legislation puts considerable emphasis on ideological development and political consciousness, and it explicitly introduces the class struggle within the peasantry inself. Within producers co-operatives, it is an objective "to give priority to the interests of poor and middle peasants and to ensure that the leadership of the association is drawn from such peasants ${ }^{78}$ ". This reflects the widespread view among Ethiopian radicals that the immediate danger in the rural land reform is continuation of a class of "rich" peasants who will exploit the mass of poorer peasants ${ }^{79}$.

Together with the strengthening of the peasant associations the new legislation takes a new view of the role of the central government. In the Rural Lands Proclamation the Ministry of Lands and Settlement (then the Ministry of Land Reform and Administration) was to be the spearhead, although in practice most

71 A Proclamation to Provide for the Organization and Consolidation of Peasant Associations, Proclamation No. 71 of 1975, Negarit Gazeta 35th Year No. 15 (December 14, 1975), hereinafter "Peasant Associations Proclamation".

72 Peasant Associations Proclamation, Art. 5.

73 Rural Lands Proclamation, Art. 10 (1).

74 Peasant Associations Proclamation, preamble.

75 Peasant Associations Proclamation, Art. 8 (1).

76 Peasant Associations Proclamation, Art. 8 (2).

77 Peasant Associations Proclamation, Art. 8 (2).

78 Peasant Associations Proclamation, Art. 8 (3). To date there is no formal definition of "rich", "middle" and "poor" peasants. An official of the zemecha indicated to the author his informal opinion that a "poor" peasant in Ethiopia is one with up to three hectares of land. A portion of this would ordinarily be grazing land.

79 See Addis Hiwet, op. cit. note 20, at pp. 112-113. 
field implementation was led by the zemecha. In the Peasant Associations Proclamation central government participation is to be achieved primarily via "Revolutionary Administrative and Development Committees" at the district, subprovince and provincial levels, and a Permanent Central Committee at the national level ${ }^{80}$. These committees, chaired at each level by the Minister of Interior or his representative, bring together officials from the ministries of Interior (including the police), Lands and Settlement, and Agriculture and Forestry, as well as representatives from the zemecha (including student participants) and the peasant associations. Thus the lead role of the Ministry of Lands and Settlement is much reduced. For the future this ministry will be occupied principally in registering and assisting in advising peasant associations, in training new personnel for local work, and in settlement projects planned mostly for lowland areas ${ }^{81}$. Indeed the ministry's new name omits the phrase "land reform", a reflection of the view that now the rural land reform is completed. In fact, some government officials now favor absorption of the ministry's remaining functions by the Ministry of Agriculture and Forestry.

\section{The Future}

At the end of the first year of Ethiopia's ambitious rural land reform, the outlook is uncertain. The present military regime is far from secure. Discontent is widespread in all levels of society, sporadic outbreaks of violence occur in several provinces, the secessionist war in Eritrea continues unabated, various government officials and others - including, occasionally, members of the ruling military group itself - are arrested, and others continue to take refuge abroad. Perhaps half the zemecha participants have left their posts, and those who remain increasingly are engaged in demonstrations against the military regime, in agitating for "peoples government", and in urging peasant associations to form their own militia ${ }^{82}$. In addition to these pressures from the left, members of former rural elites together with many in the disaffected urban middle class have the potential for a reactionary movement against the Revolution itself. Rebirth of anything similar to the ancien régime now seems highly unlikely, but reaction could bring a government well to the right of the group now in power.

With regard to rural land reform in Ethiopia, important tensions today exist between the twin goals of decentralization of power to peasant associations and egalitarianism, and for the latter goal between the initial aim of redistribution of land and the more recent objective of collective agricultural activity. In fact peasant associations today have three choices: they may form co-operatives for collective activity; they may redistribute land for individual (family) cultivation; or they may simply prefer the status quo in which, absent redistribution, individual

80 Peasant Associations Proclamation, Chapter 4

81 See A Proclamation to Provide for the Establishment of a Settlement Authority, Proclamation No. 78 of 1976, Negarit Gazeta 35th Year No. 20 (February 4, 1976). The Settlement Authority is an autonomous public authority for which the Chairman of the Board is the Minister of Lands and Settlement. Within the ministry technical functions relating to mapping and geography are also performed on a relatively autonomous basis.

82 Although the current legislation authorizes "peasant defense squads" within peasant associations, Peasant Associations Proclamation, Art. 5 (4), these squads are to carry out security and defense work only "according to the decision of the government". Id. at Art. 11 (5). At present the demand is for the government to provide these squads with weapons. 
holdings vary in size up to the de facto ten hectare maximum. Where members of the traditional rural elites gain control of the peasant association, the third choice seems the likely one. Whether the central government will wish to permit this, as well as the costs of attempting to prevent it, remain to be seen.

To date the Ethiopian rural land reforms have succeeded in two ways. First, the power of the tiny elite which controlled the land resources of most of the south, and which generally was content to let the peasantry stagnate in miserable conditions, has been broken for good. Second, land reform advisers and zemecha have in many areas of the country succeeded in mobilizing the peasants to begin through peasant associations to attack their own development problems on a local, autonomous basis. This is no mean achievement, particularly when it is remembered that never before has a political party or a national grass-roots movement for reform existed in Ethiopia.

On the other hand, the significance of the rural land reforms for much of the north remains very much in doubt. There rural elites are more closely tied to traditional local social systems than in the south, distribution of land and the elimination of absentee landownership is not nearly as needed as in the south, and penetration by any program initiated in Addis Ababa is more difficult. The option of treating northern tenure systems as themselves the basis for "Ethiopian" socialism has been rejected in favor, in the Peasant Associations Proclamation, of ideas drawn from "scientific" socialism. To implement such ideas may be increasingly difficult as the zemecha turns against the military regime and Ethiopia's left forms itself into two hostile groups. 


\title{
Agrarian Reforms and the Societal and Political Interests of Townspeople in LDCs
}

\author{
By Rolf Hanisch
}

In many LDCs - namely in Asia and Latin America - agrarian reforms are considered as one of the necessary prerequisites for an overall social development in which the lower classes also participate. However, relatively few countries have carried out effective agrarian reforms. This cannot be explained solely by the dominating political influence of the landlords, which, more of ten than not, is no longer existant. Here, it is much more the attitude of the urban strata which plays a decisive role. But, in general, their interest focused primarily on the infrastructural and industrial development of the urban area, the rural one being neglected. The aggravation of the agrarian crisis, which now also took universal dimensions, first obliged the (urban dominated) governments to intensify their development efforts in the rural area as well. These efforts, however, were extended mostly to technocratic measures of production development.

The announcement and (often only inconsequent) implementation of agrarian reforms can be mostly explained out of three situations in the political process, when the (primarily urban) elites try to extend their (rural) legitimation basis. Thereby, it can be a question of opposition groups which try to expand their legitimacy by taking up the question of agrarian reforms as their theme. By gaining power, they can try to legitimate their authority by effecting reforms and/ or who also try to withdraw the economic basis of the hitherto ruling elites. Finally, agrarian reforms can also be effected by governments which have been in power for long, if pressure is put on them. This can originate from an opposition group, a peasants' movement or from actors from the international system.

\section{Rural Land Reform in Socialist Ethiopia: The First Year}

\author{
By Harrison C. Dunning
}

In this review of the first year of rural land reform in socialist Ethiopia, the author deals with two major legislative reforms. Initially the government which overthrew Haile Sellassie adopted a Rural Lands Proclamation, which was based upon the classical notion of "land to the tiller". Cultivators were confirmed in nontransferable "possessory rights" over the land under cultivation, and provision was made for redistribution of land by peasant associations in order to give cultivators parcels approximately equal in size. These reforms were more successful in southern than in northern Ethiopia, for it was the south which had known widespread agricultural tenancy with heavy burdens placed upon the tenant. Even in the south, however, little redistribution of land from peasant to peasant took place. In a second reform, the Peasant Associations Proclamation, redistribution of land is replaced as the major goal by the development of a socialist agriculture in which the peasant association is of critical importance. The author concludes that at the end of Ethiopia's first year of rural land reform, the future was very 
uncertain. The balance between decentralization of power to peasant associations which might well preserve the status quo and egalitarian measures enforced by the central government remained undetermined, as did that between egalitarianism by redistribution of land and by collective agricultural activity.

Changes in Income, Occupation and Production in the Agrarian Sector caused by the 1969 Peruvian Land Reform

\section{By Mechthild Minkner}

The announcement of the Velasco-government's land reform law (No. 17716) on June 24, 1969, marks the beginning of a new phase in the Peruvian land reform process. According to the basic legislation, the agrarian reform is an integral process and an instrument for the transformation and reorientation of the agrarian structure. In this way, it intends to integrate the marginal groups of the rural population to the national development. At the same time the land reform is the crucial factor in order to promote agricultural development and to channel financial ressources to estimulate the industrialization. In the 1969 reform law the maximum size allowed for private landholdings has been reduced, for example in the coastal zone to 150 ha of irrigated cropland (since 1975, 50 ha), agrarian industrial complexes have been submitted to the reform, and "associative enterprises" characterized by joint ownership and self-management have been implemented as a central element of the new structure. After more than 7 years of land reform, the illusions about the great coverage of the reform mesure are gone, and we can find more than one authorized voice stating that the great mass of poor farmers and rural workers are the losers in the 1969 land reform.

The article deals with some aspects of the influence of the land reform on the land tenure patterns, on the rural income and on occupation, as well as on the development of production. However, the statistical information on the changes occured since 1969 in the agrarian sector is very poor. Therefore, the different problems can only be treated along very broad lines. The sources of data are the existing official reports, some academic research carried out on the subject and the interviews done by myself in Lima and in the country side:

Until June 30, 1976, with the expropiation of about 7,8 Million ha and 11110 properties the government has fulfilled $72 \%$ resp. $76 \%$ of the reform goal. The redistribution was carried out more slowly. The priority of "associative enterprises" in the redistribution process is very clear. Agricultural production cooperatives and the quasi-cooperative form known as SAIS are the greatest beneficiaries of the reform, having received $70 \%$ of the redistributed land. The reform has transformed drastically the land property patterns, by eliminating the property of the agricultural companies, reducing all types of relations based on rent and enlarging substantially the area and the importance of cooperative forms and peasant communities. The land redistribution is not designed to reduce the size of the very large holdings. On the contrary, now if the redistribution program is near to completed, fewer large production units will control a larger share of the country's farmland. But in the small size productive units the number of property 